\title{
THE EARLY GREEK COMMENTATORS ON THE GOSPEL ACCORDING TO ST MATTHEW.
}

THE number of early commentaries on St Matthew's Gospel, compared with the number of the commentaries on the other three, is astonishingly large, and is one of several indications of the predominant position held by this Gospel from the earliest times. A summary enumeration of them, and the natural starting-point for any systematic account, is the list given by St Jerome in the preface to his own Commentary on St Matthew, written in 387 : 'legisse me fateor ante annos plurimos in Mattheum Origenis viginti quinque Volumina, et totidem eius Homilias, Commaticumque interpretationis genus; et Theophili Antiochenae urbis episcopi Commentarios, Hippolyti quoque martyris, et Theodori Heracleotae Apollinarisque Laodiceni ac Didymi Alexandrini, et latinorum Hilarii Victorini Fortunatiani, opuscula.' Jerome, then, writing before the close of the fourth Christian century, had made personal acquaintance with the work of nine commentators on St Matthew, of whom six were Greek and three Latin.

1. Of the work of Theophilus of Antioch nothing is known outside Jerome's testimony. But Jerome refers to it also in the de viris illustribus 25, and in his r21st Epistle ad Algasiam § 6 quotes verbatim a curious exposition of the parable of the Unjust Steward, who is interpreted to be none other than St Paul. It was really, in fact, not a commentary on St Matthew alone, but on the Four Gospels put together, 'quattuor evangelistarum in unum opus dicta compingens'. This in itself hardly sounds like the second century; and in view of Theophilus's remoteness from St Jerome's day-a gap of two centuries divides them-it is impossible not to suspect some flaw in the tradition. ${ }^{2}$ But these very notices in Jerome gave a fictitious life to the supposed

1 The following study is a fragmentary commencement, written in 1903 , of what was to have been a connected account of all patristic exegesis of the New Testament. The vastness of the subject soon made contraction of the project imperative, and all that ultimately took shape was an article on 'Greek patristic commentaries on St Paul' contributed to the supplementary volume of Hastings's Dictionary of the Bible. I have no hope of ever being able to return to the subject : and it seemed to me, as I sorted some old papers, that perhaps these pages, fragmentary and incomplete as they are, might be worth rescuing from one's rubbisb-heap and transferring to the friendly shelter of the Jourmal. Here and there a sentence will be found to repeat what I have already said in print in the Hestings Dictiorary.

3 And Jerome himself seems to have had his suspicions, for he expressly notes in the deviris that the commentary on 'the Gospel' was in his opinion incongruous, in language and refinement, with Theophilus's other works. 
'Commentaries of Theophilus'; some ingenious author or scribe prefixed the name to a Latin compilation of a date not only later than St Jerome, but later also than the fifth-century writers Eucherius and Amobius Junior, and the mediaeval fraud imposed on an illustrious scholar of our own generation, who bestowed on it a temporary patronage. It will be enough on this subject to refer to a paper by Dr Sanday in Studia Biblica i (1885) 89-10r

2. In none of the ancient lists of the works of Hippolytus-neither in the inscription on the chair of his statue, nor in Eusebius $H$. E. vi 22 , nor in Jerome de viris illustribus $6 \mathrm{I}$-is mention made of any commentary on St Matthew. But the inscription is jejune about exegetical

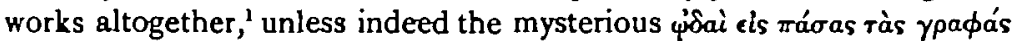
conceals somehow the meaning 'exegesis on all the scriptures'2; Eusebius subjoins to his list the note that 'very many other works' of Hippolytus would be found on research to be extant; and in Jerome's case the negative evidence of the de viris is of little moment in view of the definite statement cited above from the prologue to the Comm. in Matt. It is true that nothing like such a commentary is extant among the remains of Hippolytus : but he wrote in Greek, and Greek soon ceased to be familiar in Roman church circles, so that it is not wonderful that his books soon dropped out of sight.

That would be in itself a sufficient explanation : but there is also, in the case of the work before us, the alternative possibility that it was not really a complete commentary in the later and stricter sense at all. At the beginning of the third century, when Hippolytus wrote, the exegesis of Scripture, and perhaps especially of the New Testament, was in its infancy as a form of literature; and doubtless some experiments were tried under this head which were far from amounting to a continuous exposition from first to last of the whole of some book of Scripture.

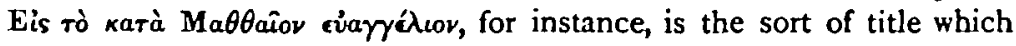
might cover exegetical work of very varying extent; and it is at least significant that all the considerable fragments of Hippolytus which can be referred with probability to the lost commentary on St Matthew attach themselves exclusively to the twenty-fourth chapter, an eschatological passage which we know, from the titles of other writings of Hippolytus, would have formed a particularly congenial theme.

(a) In Hermathena vii 137-150 (1890) Dr J. Gwynn published in

1 See Lightfoot S. Clement of Romo' ii 325 : only treatises 'on the Psalms' and 'on the Witch of Endor' are mentioned.

"All the scriptures' need not be too literally interpreted. Diodore and Theodore among the Antiochenes are both of them reported to have written roundly expositions or explanations of 'all' the books of scripture : among the Alexandrines Didymus is said to have interpreted Old and New Testament kard Aifo, 'phrase by phrase'. 
Syriac, with English translation, an extract from the commentary of Dionysius Bar Salibi on the Apocalypse (MS Brit. Mus. Rich 7185 ) embodying Hippolytus's explanation of Matt. xxiv 15-22. The margin of the MS attributes the quotation to 'the interpretation of the Gospel', i. e. apparently a definite commentary, and Harnack, Altchristliche Litteratur i $64 \mathrm{I}$, accepts, as I gather, the attribution; but Gwynn, while defending the Hippolytean authorship, speaks with reserve as to its exact provenance, and Achelis in the Berlin edition of Hippolytus (I ii 243246 : A. D. 1897 ) prints it as part of the 'Capitula against Gaius'.

(b) From Coptic, Ethiopic, and Arabic catenae, which are all derived from a single (doubtless Greek) original, Achelis, op. cit. 197-207, prints German renderings of 'interpretations' ascribed to Hippolytus, covering Matt. xxiv I 5-34.

(c) Of much greater importance than either of the foregoing, if it could really be attributed to Hippolytus, is an anonymous Latin exposition of Matt. xxiv 20-44, which Mgr G. Mercati and I myself discovered independently in the same MS of the Ambrosian Library which contains also the Muratorian Canon (I Ior sup., foll. 19-29: saec. viiviii : from Bobbio): see Studi e Testi xi (Rome r903) 'Anonymi Chiliastae in Matthaeum fragmenta', and J.T.S. v 218 (igo4) 'An exegetical fragment of the third century'. That the original belonged to pagan times I argued in the Journal both from the division of mankind into the three classes of iusti peccatores impii, and from the specific interpretation of the 'sign of the Beast on the forehead and the hand' as the laurel crown worn on the head-compare Tertullian de corona militis-and the incense cast on the altar of abomination. That a crude and materializing eschatology was still largely prevalent in the circles with which the writer is familiar is shewn by the care with which, though himself a millenarian, he sets himself to overthrow the superstition that the saints during the thousand years' reign would literally eat and drink the good things of earth at the Lord's table. That the Latin as we have it, whether it is original or a translation from the Greek, is not later than the third or. fourth century, the character of its biblical text sufficiently guarantees. If the Latin of the Ambrosian MS is a translation, then the probability was great that its ultimate source is in Hippolytus. If on the other band the Latin is original, then the claims of the earliest Latin writer on St Jerome's list, Victorinus of Pettau, ${ }^{1}$

1 Vietorinus of Petavio or Pettau, martyred under Diocletian, was according to Jerome, de viris 74, better acquainted with Greek than with Latin: but the commentary on St Matthew is enumerated by Jerome in the Latin section of his list. Nevertheless he deserves mention here, in connexion with the Greek commentators, just because it was the business of his Latin writings to put before the Latin Christian world, with however inadequate expression, the exegetical 
were very strong. In either case we seemed to have a new contribution to patristic exegesis in its most ancient period. Another feature was, however, introduced into the discussion by $\mathrm{Mr}$ Souter's proof (J.T.S. $v 608$ ) of the intimate relation between the language of the fragment and the language of the author of the commentary on the Pauline Epistles and book of Biblical Questions known as Ambrosiaster. Mr Souter claims that Ambrosiaster was himself the writer of the fragment, and that view is certainly the simplest; but I do not myself think that, especially if the original was Greek, the possibility ought to be excluded that Ambrosiaster was working up the material of an earlier writer.

3. The work of Origen, although chronologically he follows after Theophilus and Hippolytus, is for its intrinsic importance naturally placed by Jerome at the head of his list. Each of his three methods of exegesis, Commentary, Homilies, and Notes, was represented on St Matthew's Gospel : 'Origenis viginti quinque Volumina, et totidem eius Hemilias, Commaticumque interpretationis genus.' But in this case at any rate the Commentary was by far the most important of the three; and it is the only one mentioned in Jerome's lately recovered catalogue of Origen's writings' 'in Mattheum lib. xxv'.

(i) These twenty-five volumes or ró $\mu$ o of Commentary, written towards the end of Origen's life, about A. D. 245, are also mentioned in Eusebius $H$. $E$. vi $3^{2}$, and are in parts extant in the original Greek and in a Latin version.

a. Books x-xvii, containing the Commentary on Matt. xiii 36-xxii 33, were first published in the original Greek in Huet's edition, Rouen I 668:

material of Hippolytus and Origen. Compare Jerome op. 36. 16 (A.D. 384) ' Hippolyti martyris verba . . a quo et Victorinus noster non plurimum discrepat, non quod omnia plenius exsecutus sit, sed quod possit occasionem praebere lectori ad intellegentiam latiorem': ep. 6r. a (A.D. 396) 'taceo de Victorino Petabionensi et ceteris, qui Origenem in explanatione dumtaxat scripturarum secuti sunt et expresserunt' : ep. 84. 7 (A.D. 400) 'nec disertiores sumus Hilario nec fideliores Victorino qui eius [se. Origenis] tractatus non ut interpretes sed ut auctores proprii operis transtulerunt '. Similarly Rufinus (Apol. ii 30 ) asserts ' de sancto Victorino' that he was not strictly a translator of any Greek work, 'interpretis titulo nihil omnino arbitror transtulisse de graeco'. No direct quotations appear to have survived from Victorinus's work on St Matthew : Jerome even omits all mention of it in the catalogue of Victorinus's writings in the de vinis, and Cassiodorus's reference suggests that Victorinus, like Hippolytus, may have dealt only with selected passages, de inst. div. litt. 7 'Hattheum ... de quo et Victorinus ex oratore episcopus nonnulla disseruit'.

1 The catalogue is a fragment of a letter to Paula and Eustochium of A.D. $3^{8} 4$ : printed in Harnack Altchristliche Litteratur i 334, and (with the help of further MSS) by Klostermann in the Sitonngsberichte der k. proussiscten Abademie der Wissenschaften, 1897, P. 855 . 
see de la Rue iii 442-829, Migne $P$. $G$. xiii 835-r6oo. The MSS are enumerated, and their relations discussed, by A. E. Brooke, Fragments of Heracleon ('Texts and Studies' i 4, A. D. I89r) pp. I-I 7 ; by Preuschen in Harnack's Altchristliche Litteratur i $39 \mathrm{r}, 392$; and again by Brooke Commentary of Origen on St John (Cambridge, A. D. 1896) pp. xviii, xix. Munich graec. cxci, saec. xiii, is the oldest MS and is the direct ancestor of some at least of our other MSS.

B. The Commentary on Matt. xvi 13-xxvii 66 is represented in a Latin translation, first edited by Merlin, Paris 15 I 2, omitted by Huet, but restored to a place among Origen's collected works in de la Rue iii 52I-93 I, Migne $P$. $G$. xiii 993-1800. It commences at tom, xii $\$ 9$ of the Greek, and is divided into tractatus, numbered from $I$ to $35^{1}$ Preuschen, op. cit. $3^{66}$, explains by reference to these thirty-five tractatus the error in Jerome's prologue to his translation of Origen's Homilies on St Luke 'xxxvi tomos illius [sc. Origenis] in Mattheum': but the figure there should doubtless be read not xxxvi but xxvi, in accordance both with a Cambridge manuscript of the Latin Homiliae, ${ }^{2}$ and with Rufinus's citation of this very prologue of Jerome's in adv. Hicron. ii 2 r, 22.' For the date of the version we are thrown back therefore on other evidence than Jerome's. Termini ad quem are the following: one MS, used by de la Rue, had been given to St Remi at Reims by archbishop Hincmar, who died in 882 : the translation is used in the Commentary on St Mattheze of Paschasius Radbert, abbot of Corbie, who died in 85 $x$ : and finally it is not likely that any Western scholar would have had access to any treatise of Origen, much less have wished to translate it, later than the sixth century. In the opposite direction, as a terminus a guo, Dom Chapman (J.T.S. iii 436 [1902]) sought to establish the dependence of the translator on the Latin commentary known as the Opus imperfectum in Mattheum, an Arian work composed at earliest about A. D. 400. Chapman argued that the translator was a bishop: Huet had suggested Cassiodorus's friend the presbyter Bellator, the known translator of Homilies of Origen on the two books of Esdras (circa A. D. 550). From comparison with the original Greek in the five or six tomes for which they overlap, the work appears to be rather a paraphrase than a translation. Yet even so, and inelegant or even barbarous as it is, de la Rue was able, in defending its re-inclusion in his edition of Origen (pref. ad vol. iii), to appeal to its services in emending the text, and establishing the meaning, of the original Greek.

1 The division into $\mathrm{I}_{45}$ 'series' or sections, by which it is now usually cited, is due to the editors (presumably to de la Rue), and only commences from the point where the Greek text fnils us, Matt. xxii 33.

2 MS of Corpus Christi College, of about A.D. 800 : see Westcott Ditt. Christ. Biogr. iv 113 a.

- Preuschen's reference here is wrong. 
(ii) The twenty-five Homilies rest on the single guarantee of Jerome's preface to his Commentary. No other ancient authority mentions them : and the various homilies on texts taken from this Gospel which are found in Latin mediaeval MSS-the Venice ${ }^{1}{ }^{1} 3$ edition of Latin Homilies of Origen includes e.g. sixteen on St Matthew-appear to have no claim to genuineness.

(iii) The Notes on St Matthew, 'commaticum interpretationis genus', are similarly known only from the same preface of Jerome.

But how does it come about (it may be asked) that Jerome should enumerate in this preface, among books read by him long before, two works of Origen on St Matthew which are yet absent from the presumably exhaustive catalogue of Origen's writings sent only three years earlier, in 384 , to Paula and Eustochium ? It is an apparent rather than a real contradiction: for the list in the letter to Paula is taken over bodily from Eusebius's Life of Pamphilus, and the absence of the Homilies and Notes on St Matthew from the list means not that they were unknown to Jerome but that they were unknown to Eusebius.

Of fragments of Origen on St Matthew the following will be found in print :-

a. In Eusebius $H$.E. vi 25 : from the Commentary, tom. i.

b. In the Philocalia c vi (ed. Robinson pp. 49, 50): from the Commentary tom. ii (on Matt. $\nabla 9$ ).

c. In Pamphilus's Apologia pro Origene as translated by Rufinus, cap. v 'responsio ad quintam criminationem' (de la Rue iv appendix p. 36) : from the Commentary, tom. i. And in the same work, cap. $x$ (de la Rue iv app. pp. 45, 46): two passages from the Commentary tom. xi and tom. xiii.

d. In Possinus's catena on St Matthew (Toulouse 1646: from a manuscript of archbishop de Montchal of Toulouse) are seventy-one quotations under the name of Origen: Matt. i 1, 5, 16, 18, 18 bis; ii 2, I1, I3, I8; iii $4,14,17$; iv $2,11,12,16,17,22 ;$ v $5,7,8,9,10,16,17$, $22,25,28,37,45,48$; vi $\mathrm{I}, 5,3 \mathrm{I}$; vii 2,22 ; viii $20,32 \mathrm{f}$; ix $2,9,30$; $x 2,6,16,23,24 \mathrm{f}, 26$; xi $17,19,24$; xii $28,39 \mathrm{f}$; xiii $32,33,33$ bis, 44 ; xiv 19,20 ; xvi 28 ; xvii 6 ; xviii 21 ; $x i x 12,24 ; x x 1,16$; xxi 1 ; xxiii 8 ; xxiv 15,28 ; xxvi 8,45 . That the quotations become relatively infrequent in the later chapters is probably due more to the slackness of the Catenist than to anything else; not only Origen but other fathers as well are cited less often for these chapters, and the catena becomes more and more a mere series of extracts from St Chrysostom. The Origenian quotations we shall naturally expect to have been drawn principally from the Commentary, the only form of Origen's work on this Gospel which we know to have been cited by subsequent writers. But assuming that the labels are correct and that erroneous ascription cannot 
have affected more than a small proportion of the quotations, this expectation is not in fact fulfilled. If the quotations and the Commentary be compared for the chapters where the latter is extant-Matt. xiii $3^{6-}$ xxii $33^{-}$-it results that, among many resemblances in thought, there seems to be no single case of identity in expression: the nearest likeness is perhaps in the comment on Matt. xvii 6 (Possinus p. $24 \mathrm{l}=\mathrm{de}$ la Rue iii 564), yet even there it does not extend throughout the citation. Either then the Catenist habitually summed up in his own words the subject-matter of long passages of Origen, or he must have borrowed as a rule from some other work than the Commentary. And in fact there do occur, as Origen's, expositions of the text which, though they may well be Origen's, are not the actual expositions given in the Commentary. Many of the citations, too, have a pregnant brevity which suggests derivation neither from a commentary nor yet from homilies-for Origen as a commentator and a homilist is not brief-but from the Notes, the ' commaticum genus' of St Jerome's preface. Take for instance the Parable of the Labourers in the Vineyard, Matt. xx $1-7$. Here the Catenist quotes as from Origen the pithy explanation оікодеспо்тнс $\mu$ év

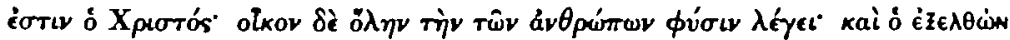

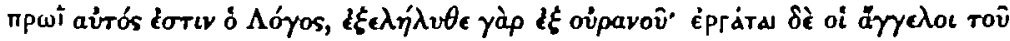

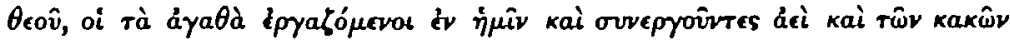

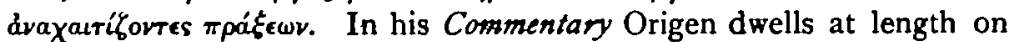
the same parable, giving first an elaborate allegorical exegesis, and then a simpler one, 'useful for those who stumble at the deeper and more recondite explanation': according to the former the labourers represent the different covenants of God with man, in Adam, Noah, Abraham, Moses, Christ ; according to the latter the different periods of man's life-infancy, youth, manhood, old age, death-bed-at which the call may come to enter the Vineyard of the Church. But nowhere does there appear to be any bint of an identification of the iprára with the angels.

In Corderius's catena on St Matthew ${ }^{1}$ there are, as far as I have noticed, no citations of Origen.

e. At the close of Gallandi's Bibliotheca Vestum Patrum (vol. xiv [Venice A.D. I 78I] appendix pp. 73-83) is a series of fragments of Origen on St Matthew, collected from catena MSS of the library of St Mark's. The passages of the Gospel to which they relate are as follows : Matt. i 18 ; vii $5,6,9$, 10 ; viii 11 ; xi 11,12 ; xii 14,15 ; xiii 44,47 ; xviii $5,20,21$; xxi 33 ; xxiv 45 ; xxv I; xxvii I I, 45 ; xxviii I 8 .

1 Corderius s catena on St Matthew (which is that of Niceta of Serreg) was published at Toulouse in 1647 , as a sequel to that of Possinus : his catenae on St Luke (a Latin version only) and St John had been published some years earlier at Antwerp, in 1628 and 1630 . 
Of this series there is no doubt that the Commentary was the source; wherever comparison is possible, not only the ideas but the salient expressions are found to correspond. The Catenist abbreviates and summarizes, and his text as printed is often obviously corrupt. There can therefore be no question of recovering, on his authority alone, any of the ipsissima verba of losi portions of the Commentary; yet it would be interesting enough if we could refer to Origen even the substance - of the comment, for instance, on Matt. i 18 , the distinction between

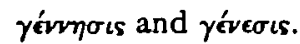

$f$. The catena of Cramer on St Matthew (Oxford 1840 ) is derived from two MSS, the one at Paris, coislin gr. 23, saec. xi, and the other in the Bodleian, Auct. T. I. 4, saec. x. There are about the same number of citations from Origen as in Possinus: Matt. (i 1 9, 25); ii (7) $\mathrm{r} 8$; iii 1 ; v $(33), 45$; vi 3 ; vii 27 ; viii $8,11,22,34$; ix $17,24,30,37$; $x$ 9, 23, 32, 34; xi $3,9,16-17,25$; xii $1,{ }^{1} 6,10,20,22,33,44,50$;

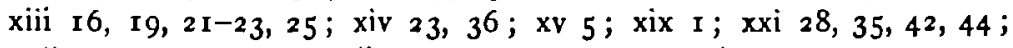
xxii 4, 6-9, 11, 13; xxiii 25, 27, 31-32, 37; xxiv so; $x x v 24,34$; (xxvii 27); xxviii 9 : viii 34 , xii 50 , xiii 16 , xxi 42 , have two quotations apiece. On the one hand these quotations not only run to greater length than those in Possinus, but also shew much more unmistakeable points of contact with the Commentary. On the other hand Cramer's catena reveals evidence of carelessness in the way of double ascriptions and blunders in the way of false ascriptions, whether these are to be attributed to editor, collator, or scribe. An exposition of the parable of the Two Sons, Matt. xxi $29-31$, is certainly taken from the Commentary (Cramer p. $173=$ de la Rue iii 770 ), though reference to the original text is necessary to make intelligible the abbreviated and corrupted passage in Cramer. A beautifully drawn out contrast between those who 'only touched the hem of his garment' (Matt. xiv 36 : Cramer p. I19) and those who enjoyed the fullness of Christ in the Eucharist is absent from de la Rue's text, and is perhaps falsely labelled with the name of Origen. Among the more interesting notes, in the parts not represented by the continuous Greek or Latin of the Commentary, are those on Matt. v 45 ; viii 11,12 ; ix 30 ; xii 46-50 (Cramer 42. 8 ; 59. 31; 71. 30 ; 99. 24). The unintelligent methods of the editing may be gauged from Cramer

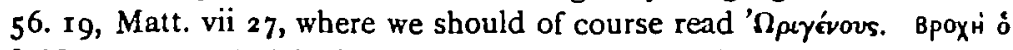

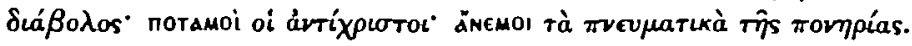

1 This long passage is introduced with the words eloais $\delta$ \&forórns Xperós, and the use of the title searirts rather points away from Origen to the later Antiochene School.

'In the case of Cramer's catena on a Corinthians, Mr Jenkins has shewn (J.T.S. vi I 3 ) that many citations which the edition puts down to Origen are, in the MS from which the text was taken, correctly ascribed to Chrysostom. 
In the result it must be admitted that the catenae on St Matthew, or at any rate such of them as are yet printed, contribute rather little to an exact knowledge of Origen's exegesis. The very meaning of a catena was to be multum in parvo, to summarize in handy form the best exegetical matter of different writers and different schools : and no one lent himself less easily to such a system than Origen, who beyond all others was accustomed, as Jerome phrases it in the prologue to his translation of Origen on Ezekiel, to 'spread the full sails of his genius to the favouring winds'. With other writers the value of catenae will be greater : but in the case of Origen there will be too much reason to fear that the selections of one Catenist may have been abbreviated by another and perhaps epitomized by a third, until the original, if we had it, might be barely discernible in the quotations that profess to represent it.

Besides catenae and similar fragments professing to be quoted directly from Origen, it must be borne in mind that a large amount of Origenian matter is preserved in later commentators, especially in Western writers such as St Hilary, St Ambrose, and St Jerome. But in distinguishing this from other elements of a composite work, we have of course to rely, where the original is not extant, only on internal criteria.

4. Theodore, bishop of Hereclea-Perinthus in Thrace from before $34 \mathrm{I}$ till his death circa $355-35^{8}$ : said to have been a pupil of Lucian of Antioch, therefore before 3rI, the year of Lucian's martyrdom : a leader of the moderate Arian party, one of the earliest and ablest exegetes of the Antiochene school, and perhaps the first of all Christian exegetes whose work was devoted mainly to the New Testament. Of the books of the Old Testament, be wrote on the Psalms; of those of the New, on St Matthew, St John, and 'the Apostle'. Jerome, de viris 90 , praises the clearness of his style and his historical intelligencequalities, of course, specially characteristic of the great Antiochene expositors. Theodoret, $H$. E. ii 3 , places his 'remarkable eloquence' and his 'interpretation of the divine Gospels' in immediate connexion with the influence which, as bishop of an important see in the near neighbourhood of the capital, he exercised in the Arian direction over the mind of the emperor Constantius. Of all these New Testament commentaries nothing remains outside the catenae. The whole of the large Arian literature of the fourth century has disappeared with such minute exceptions, that it is extraordinarily difficult to recreate for ourselves even in imagination the chronicles, the histories, the commentaries, which, no less than works which were primarily theological, fell under the ban of heretical authorship, and disappeared in course of time simply because no one would any longer be at the pains of copying them. It was only in selections, where care could be taken to supervise the 
doctrinal innocency of the parts selected, that heretical writings could ultimately hope to survive : as St Cyril of Alexandria puts it, with no

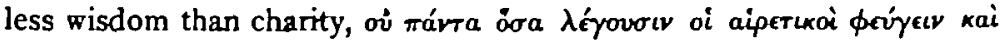

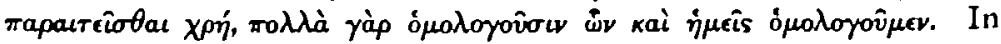
days when the increasing sensitiveness of Byzantine orthodoxy was closing all ordinary avenues of circulation to the writings of many even of those who had died in full communion with the Church, the catenae still kept a half-open door for Origen and Theodore of Heraclea and Eusebius of Emesa and Apollinaris of Laodicea and Diodore of Tarsus and Didymus of Alexandria and Theodore of Mopsuestia.

Of the printed catenae on St Matthew Possinus contains twenty-three quotations under the name of Theodore of Heraclea, Corderius only two, Cramer thirty-seven. ${ }^{1}$ And even in the estimate of these few quotations the usual deductions necessary for catenae must be made. Thus, four are common to Possinus and Cramer, but in each case considerable differences exist between the two forms of text. In one of them, the exposition of the parable of the Talents (Matt. xxv 14-30= Possinus $33^{8}$, Cramer 210), the advantage lies on the side of Cramer ${ }^{2}$; in the comment on the feeding of the 4000 (Matt. xv $33 \mathrm{ff}=$ Possinus 225, Cramer I 28) Possinus, though the shorter, is by far the more intelligible; upon the 'abomination of desolation' (Matt. xxiv $15=$ Possinus $3 \times 7$, Cramer 196 ) the two catenae if not inconsistent are at any rate divergent, the fuHer statement in Possinus being also the more probable; while for the fourth we have to choose between the authorship of Theodore (Possinus) and Apollinaris (Cramer) for an exposition, verbally identical in the two catenae, of the 'temple and the gold in the temple' (Matt. xxiii $16=$ Possinus 307, Cramer 189). A further and special risk of confusion attaches to the name Theodore : besides Theodore of Heraclea the catenae cite both Theodore of Mopsuestia (also called Theodore of Antioch) and Theodore the Monk. Thus if we find, in a comment on Matt. iv 4 , given by Cramer p. 25 under the

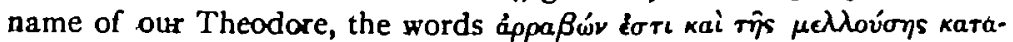

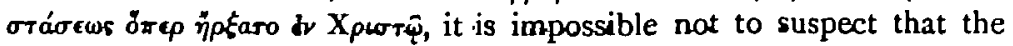

I One of Cramer's quotations, p. 176, has, besides the name of Theodore,

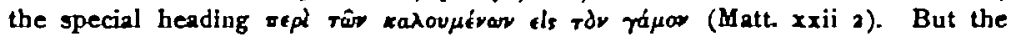
quotation consists actually of a summary explanation of the parable of the Vineyard and the Husbandmen, Matt. xxi 33, and appears therefore to have been misplaced in the MSS, so that all reason for conjecturing the existence of some special source other than Theodore's Commontary, such as a Homily on the WeddingGuests, disappears.

In the exposition of this parable Chrysostom appears to follow Theodore of Heracles.

8 There is little doubt that Cramer is here right with Apollinaris, for, as it happens, he has already given a comment from Theodore of Heraclea on the passage. 
true author is Theodore of Mopsuestia, with whom no idea is more

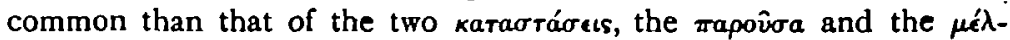
Aovoa, and the 'commencement' of the second in the earthly life of the

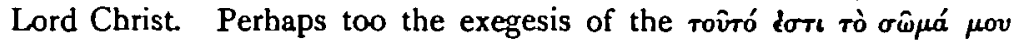
(Matt. xxvi $26=$ Possinus 349 ) may be thought to be wrongly ascribed

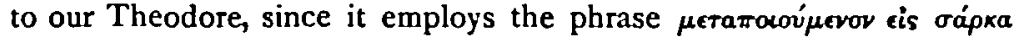

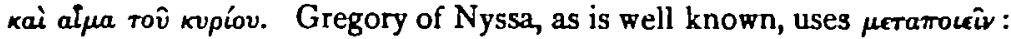
but if the catena comment is really from Theodore of Heraclea, the use of this language is taken a generation further back.

Two of the catena fragments, if they are rightly attributed, shew clear trace of the influence upon Theodore of Origen. Perhaps the earlier Antiochenes weie not so personally antagonistic as their successors to the great Alexandrine, and there are departments of Gospel exegesis, such as in particular the exegesis of the parables, where the antinomy of the literal and the allegorical had less play than elsewhere: and of course Origen was not always allegorical. Anyhow both Origen and Theodore on Matt. $\times 23$ (= Cramer 78. 14, 26) explain that the 'coming of the Son of Man' is not the final return in glory but that in which He shews Himself 'from time to time' to the Saints : and in the parable of the Vineyard and the Husbandmen (Matt. xxi $33-4 \mathrm{r}=$ de la Rue iii 772, Gallandi xiv appendix $78=$ Cramer 176 ) the resemblance is so close that it might even be thought that the ascription to Theodore in Cramer is a mistake for Origen. An allegorizer after the Alexandrine fashion Theodore of course was not: what he has borrowed from Origen is plain straightforward stuff. If we except the undoubted comment on Matt. xxiii 16, where the putting of the gold above the temple is explained as an aiviypa of the preference of the Jews for Moses over Christ, Theodore is on the whole a strict adherent of the literal sense. Even where numbers are concerned-the greatest of all temptations to allegory-such as the 'fourth watch' of Matt. xiv 25 or the 'twelve apostles' of Matt. $\times 2$ (Possinus I 34, 2 I I), he refuses to launch out into the deep ; the number and names of the apostles were exactly recorded, he tells us, simply in order that the faithful might have a criterion at hand whereby to distinguish true apostles from false. Other interesting notes are those on Matt. i 18 (Poss. I2); ii 15 (Poss. 30 : the quotation is referred to Num. xxiii 22); $v 42$ (Poss. 78 ); $x$ 34-36 (Poss. 148 ); $x$ 42 (Cr. 82); xii 20, 2 I (Cr. 92); xv 32 (Cr. 127); xviii 8 (Poss. 252 : the offending hand or foot are offending members of the Church); xix 9 (Cr. $15 \mathrm{I}$ ), ஸ்

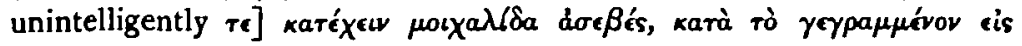
Soגopî̀ra.

Just enough then still survives to give us some idea of the standpoint and method of the earliest and not least capable of the expositors of the 
historical school. Obviously Theodore was a clear, succinct, sensible commentator, free from the faults (if we ought not rather to call them the merits) alike of Origen and of his own namesake of Mopsuestia. It is not likely that his Arianizing belief seriously affected the value of his expositions, at any rate of the Gospel of St Matthew ; and their loss is greatly to be regretted.

5. Apollinaris (or Apollinarius), bishop of Laodicea in Syria and eponymous author of the Apollinarian beresy, died, apparently in possession of his bishopric, circa A. D. 390 . St Jerome, in the de viris ro4, speaks of him as 'in sanctas scripturas innumerabilia scribens volumina' but is silent about his doctrines : in his eighty-fourth epistle (A. D. 400) he says more expressly still 'Apollinarium Laodicenum Antiochiae frequenter audivi et colui,' et cum me in sanctis scripturis erudiret numquam illius contentiosum super sensu dogma suscepi'. Whatever Jerome's faults, lack of gratitude to his teachers was not among them: and no doubt Apollinaris's services in resistance to the long dominant Arianism of the East inclined Jerome, as it inclined Athanasius, to an indulgent estimate of his teaching. But while the Catholics of Egypt and the West were thus kindly disposed to Apollinaris, the school of Antioch, Catholics and Arians alike, cherished a special resentment against the theological conceptions which took their name from him : the bias of Theodore of Mopsuestia, the system of Nestorius, were alike produced by reaction from it, and it was long before the antiCyrilline leaders, John of Antioch and Theodoret, could be persuaded that the Alexandrine emphasis on the formula of the Theotocos was not motived by an unavowed leaning to Apollinarianism. Thus it was just in his own district-Laodicea was close to Antioch, and it was actually at Antioch that Jerome heard him lecture-that the movement in his disfavour was strongest; moreover it was just in the sphere of exegesis that the school opposed to him held the field throughout the fifth century, while his own followers rather concentrated their efforts on the circulation of his doctrinal treatises, which for safety's sake they often placed under the shelter of names of admitted orthodoxy. Naturally therefore the commentaries of Apollinaris, whatever their intrinsic merit (and for that Jerome would alone be a sufficient guarantee), were doomed to early oblivion. Even the catenae - there is good reason to conjecture that catenae as a form of biblical literature developed first at Antioch-made but sparing use of him. Jerome, as we have seen, speaks of a commentary on St Matthew : but of the catenae on that Gospel, Possinus has only sixteen citations from him, Corderius

1 Either in A. D. 374 or 379 For further detail of the use which Jerome made of Apollinaris's writings, see the preface to his commentary on the epistle to the Ephesians. 
none, Cramer eleven. Nevertheless, few as they are, they are of extraordinary interest. His comments on St Paul reveal him as on the whole an Antiochene rather than an Alexandrine exegete, in agreement with Theodore of Heraclea and Diodore against Didymus and Origen. Here on the Gospel we should perhaps rather place him midway between the two schools. If less diffusive than Origen, he has none of the succinctness of Theodore of Heraclea. Interest in the historical sense of the letter of scripture is subordinate to interest in the theology : compare the notes on prophecies (Matt. ii 18 , viii $17,29=$ Possinus 32, 1 3 , I 19); on our Lord's reserve in working miracles (Matt. xiv I9, xvi $4=$ Poss. 208, 227); on the Word as creator (Matt. xix $4=\mathrm{Cr}$.

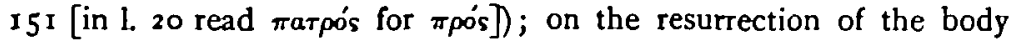
(Matt. xxii $32=$ Cr. 183 ); on chastity as a natural gift (Matt. xix 1 I =

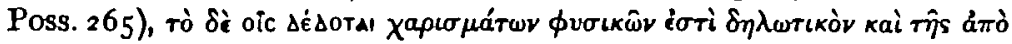

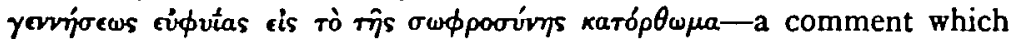
Chrysostom appears to have directly in view when he writes ad loc.,

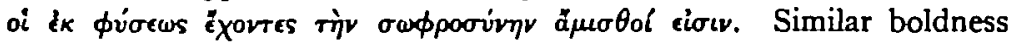
characterizes his exegesis of Matt. i 16 (Poss. 10 ), on the sense in which Joseph can be rightly called 'father' of Christ both kard̀ xápıv and кarà бápкa, or of Matt. xii 48 (Cr. 99 : cf. Luc. ii 34, 35), the Mother herself 'spoke against' Christ 'for a time'. He does not shrink from contrasting (Matt. xxiii r6-r9 = Cr. r89) the letter of the Gospel statement with the spiritual reality of the Christian dispensation, where the gold is greater than the temple and the gift than the altar, 'for the gold in the present spiritual temple of God is the Spirit itself, and the gift on

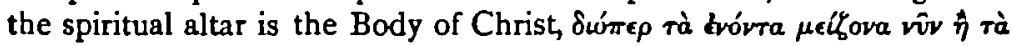
$\delta$ xópeva, for it is the former that sanctify and the latter are sanctified by them'. Among other comments may be noted those on Matt. xii I 9 (Poss. I 70); xix 8, 9 (Cr. I5I); xxv 24, 25 (Poss. 338); xxvii 5 (Cr. 23I, ll. $\left.\mathrm{II}_{\mathrm{I}} \mathrm{r}_{3}\right)$, where Papias is cited at some length for the fate of Judas. ${ }^{1}$

The Church historian Socrates must be speaking of a different work from the Commentary, when he tells us $(H . E$. iii 16) that under Julian Apollinaris 'published ( $1 \xi \dot{\theta} \theta$ cro) the Gospels and the Apostolic teaching in the form of Platonic' dialogues. The discourses in St John, and the epistle to the Romans, may have lent themselves to this manner of treatment, and the parallel cases cited in Socrates imply clearly that the biblical books themselves were rendered into classical form. It is hardly possible therefore to translate $\& \xi \notin \theta$ cro 'expounded', and to understand the reference to be to a commentary on the Gospels by way of

1 The same passage is given, and again as from Apollinaris, in Cramer's catena on Acts P. 12: the source in both cases is no doubt the Commontary on St Matthew. 
question and answer : for in commentaries of that sort not the question but the answer is the really important thing, whereas the converse is the case with dialogues 'after the manner of Plato'.

6. Didymus, presbyter of Alexandris and head of the catechetical school, born about A. D. 3.09, died between 392 and 400 . Fer figures even among the churchmen of the fourth century present greater fascinations than the indefatigable scholar and theologian, who, in spite of total blindness from early childhood, mastered all the secular and sacred science of the day, and was appointed by Athanasius to the post that had been held by Clement and Origen. At the great catechetical school he numbered among his hearers both Jerome and Rufinus. It was to the exegesis of scripture that Didymus especially devoted himself: Palladius Historia Lausiaca $\$ 4$ tells us that he 'interpreted Old and New Testament phrase by phrase'; Jerome, de viris ro9, after cataloguing some ten works, nearly all of them commentaries, adds that there were countless others 'quae digerere proprii indicis est', and the same writer in his prologue to the Comm. in ep. ad Ephesios says that he went to Alexandria to see Didymus and to question him on any points of doubt over the whole of the Scriptures. That a commentary on St Matthew was among his writings is made certain by Jerome's statement both in the de viris and in the prol. ad Comm. in Matt. Yet none of the printed catenae appear to have preserved any citations from it: another proof that to have been an Alexandrine and a follower of Origen entailed in the circles of catenists and scribes a more stringent ban than open Arianism or Apollinarianism or Nestorianism in the more favoured writers of Antioch.

C. H. Turner.

\section{'A NEW NAME' (NOT 'ANOTHER NAME'), ISAIAH LXV I5.}

THE two readings in this passage (kawó LXX, ר. M.T.) present practically the same meaning. Indeed the fact that the LXX does represent a Hebrew variant has commonly been overlooked. Thus Mr Ottley writes: 'kauvòv is not quite exact, but may have been meant to harmonize with ver. 17.' But kaurov is not a loose rendering. Elsewhere in Isaiah and throughout the whole of the LXX kavos invariably stands for remains almost unaffected, whichever reading be adopted, the way in which the one reading seems to have been evolved out of the other is not without interest. The explanation here given elucidates moreover another small textual point in the context. 